\title{
Design and Feasibility Analysis of a Solar PV System for Street Lighting in a University Campus
}

\author{
Muhammad M. Hasan* \\ Department of \\ Industrial and \\ Production \\ Engineering, Shahjalal \\ University of Science \\ and Technology, \\ Sylhet-3114, \\ Bangladesh.
}

\author{
Md. Rabiul Hasan \\ Department of \\ Industrial and \\ Production
}

Engineering,

Shahjalal University

of Science and

Technology, Sylhet3114, Bangladesh.

\author{
Ranjit Biswas \\ Department of \\ Industrial and \\ Production
}

Engineering,

Shahjalal University

of Science and

Technology, Sylhet-

3114, Bangladesh.

\author{
ABM Abdul Malek \\ Department of \\ Industrial and \\ Production
}

Engineering,

Shahjalal University

of Science and

Technology, Sylhet-

3114, Bangladesh.
Md. Masum Parvej
Department of
Industrial and
Production
Engineering,

Shahjalal University

of Science and

Technology, Sylhet-

3114, Bangladesh.

\begin{abstract}
Due to global concern on climate change, renewable energy is also attracting both public and private investments to supply energy in Bangladesh as a developing country. Increasing the percent share of total energy produced from renewable energy is vital for achieving a sustainable energy growth. In this research paper, a PV(photovoltaics) solar system has been designed for the purpose of street lighting at Shahjalal University of Science and Technology (SUST), Sylhet, Bangladesh. The analyses for economic feasibility and greenhouse gas emission of the proposed solar street lighting system have been conducted using a clean energy management software namely 'RETScreen'. For a project lifetime of 25 years, the equity payback period for the solar PV system is found to be as low as 13.6 years. The internal rate of return (IRR), net present value (NPV), benefit cost ratio (BCR) and annual life cycle savings are found to be about 7\%, BDT 35690, 2.6 and BDT 1430, respectively. As a result, it can be concluded that the implementation of the solar PV systems is economically viable. Moreover, a total reduction of 11.42 tons of $\mathrm{CO}_{2}$ emission per year is expected from replacing fossil fuel based electric energy which indicates a great environmental impact for the better world.
\end{abstract}

Keywords: Solar energy, photovoltaics (PV), street lighting, financial analysis, emission analysis.

\section{INTRODUCTION}

Bangladesh is a developing country of South-Asia with a large population. For maintaining the lifestyle of its citizens, it has a huge energy demand. Mitigating the existing energy crisis is a great concern for its government. Throughout the world fossil fuel is the main source of energy with a contribution of $79.68 \%$ of total energy consumed whereas Bangladesh consumes $73.8 \%$ of total energy [1]. Energy from electricity is the most vital form of energy in Bangladesh. It gets most of its electric energy from fossil fuel where the largest share is from natural gas about $46.96 \%$ of total energy and the share of electricity from heavy fuel oil (HFO), captive power plants, high speed diesel (HSD), imported electricity, coal and renewable energy are $22.43 \%, 10.71 \%, 10.61 \%$, $5.64 \%$ and $2.16 \%$, respectively [2]. However, the fossil fuel is not inexhaustible. Wadud et al. [3] reported that in the year of 2030, the forecasted gas consumption in Bangladesh will be double of its present demand. The energy sector will have to face this growing demand of energy. Supplying the whole energy from fossil fuels will be devastating for the earth. Renewable energy sources such as solar, wind, biomass and hydro power can be the probable alternatives to offset the energy crisis not only for Bangladesh but also for the world.

Energy obtained from sunlight striking the earth in one hour is more than the energy consumed by human in one year [4]. In Bangladesh the present share of renewable energy to the total energy generation is only $1.49 \%$ where the major portion of total renewable energy $(61.1 \%)$ is from solar energy [2]. Solar energy is the most abundant sources of renewable energy. It's one of the most potential renewable energy attracting significant drive to be harvested across the world. Due to the geographical location of Bangladesh, between 20.30-26.380 north latitude and between 88.04-92.440 east longitude, it has a great potential to harvest solar energy [5]. With an increasing attention towards carbon-neutral energy production, solar electricity using photovoltaic (PV) technology is receiving heightened attention as a promising approach towards sustainable energy production. Energy requirement for a university sourced from renewable energy will obviously play a vital role for reducing fossil fuels consumption.

Shahjalal University of Science and Technology (SUST) located at a city, namely, Sylhet in Bangladesh is a green campus having a green panorama and hills with a number of tourist attractions. Solar PV systems for street lighting is expected increase its tourist attraction. system can play a vital role in this issue. Average global solar insolation in Sylhet during 1988-98 considering the whole year was reported as $4.54 \mathrm{~kW} / \mathrm{m} 2$ /day [6]. Sustainable solution using solar have been explored for a variety of application such as solar boat, solar-powered wheel chair, solar powered base station of mobile networks, etc. [7,8]. Sowe et al. [9] investigated on the economic viability of a c-Si module based power plant and found it as an economically feasible alternative. In their work, they also found that the IRR, PBP, BCR were $9 \%, 8.35$ years and 1.82, respectively. Mondal [10] argued that only financial analysis is not sufficient to appreciate the investment on energy sectors, environmental impacts should be assessed as well. In a research, Aung and Myint [11] investigates a solar PV system for the purpose of street lighting.

So far, the literature survey reveals that there is a scarcity of research work done investigating on the economic feasibility 
of solar PV systems for street lightings. The present work aims at designing a PV(photovoltaics) for the purpose of street lighting at Shahjalal University of Science and Technology (SUST), Sylhet, Bangladesh. The economic feasibility and $\mathrm{CO}_{2}$ emission savings by implementing the proposed solar street lighting system have been conducted using a clean energy management software namely 'RETScreen'.

\section{METHODOLOGY}

At first, the relevant data were collected from the existing street lighting system to calculate the required energy for an electric poll. After a market survey, the suitable models for solar panels, storage batteries, charge regulators and the LED lamps were selected. The sizing of the solar PV system has been conducted on the basis of previous research works $[12,13]$ that is detailed at the results and discussion section. For the analysis of the economic viability and estimation of the greenhouse gas emission, a clean energy management software namely 'RETScreen' and the wellknown Microsoft Excel are used.

The net present value (NPV), internal rate of return (IRR), benefit cost ratio (BCR) and payback period (PBP) methods are determined using the RETScreen software to check the economic viability of the proposed solar project. The NPV for the life cycle cost of the solar project is also calculated using the Microsoft Excel.

Net Present Value (NPV) shows the difference between the present value benefit and present value cost, which can be calculated as below [9]:

$$
N P V=\sum_{n=0}^{N} \frac{\mathrm{P}_{\mathrm{n}}}{(1+\mathrm{i})^{\mathrm{n}}}-\sum_{\mathrm{n}=0}^{\mathrm{N}} \frac{\mathrm{Q}_{\mathrm{n}}}{(1+\mathrm{i})^{\mathrm{n}}}=P V B-P V C
$$

where, $P_{n}$ is expected benefit at the end of year n, $Q_{n}$ is expected cost at the end of year $\mathrm{n}, \mathrm{i}$ is discount rate, $\mathrm{n}$ is project duration in years, $\mathrm{N}$ is total project period, $\mathrm{PVB}$ is present value benefit and PVC is present value cost.

The interest rate which can be earned on the unrecovered project balance of the investment, is known as the internal rate of return (IRR). The internal rate of return (IRR) can be determined while the discount rate, $\mathrm{i}$ equals to IRR and $\mathrm{NPV}=0$ using the following equation [9]:

$$
\sum_{n=0}^{N} \frac{\mathrm{P}_{\mathrm{n}}}{(1+\mathrm{i})^{\mathrm{n}}}-\sum_{\mathrm{n}=0}^{\mathrm{N}} \frac{\mathrm{Q}_{\mathrm{n}}}{(1+\mathrm{i})^{\mathrm{n}}}=0
$$

The benefit cost ratio (BCT) is estimated from the ratio of the total present value benefit (PVB) with the total present value cost (PVC) as below [9].

$$
B C R=\frac{P V B}{P V C}
$$

Payback period (PBP), $\mathrm{N}$ is calculated as the period in years while the following equation is satisfied [9]:

$$
\sum_{n=1}^{N}\left(P_{n}-Q_{n}\right)=0
$$

If the net present value(NPV) is greater than zero, it means that the project will add value to the farm or investor and create wealth for shareholders [14]. If the IRR is greater than the discount rate, the PV project is considered as the acceptable and viable project. The BCR value greater than one indicates the profitable PV project. Life-Cycle Costing (LCC) is the sum of all significant costs incurred for a product or a project over its lifetime and is determined by adding all relevant costs [15].

\section{RESULTS AND DISCUSSION}

In order to assess the existing grid-connected lighting system established at different roads in the studied university campus, the existing number of electric polls were counted and found to be about 126. The details of different sorts of electric lighting systems currently available in the campus including the peak energy consumption are given in Table 1 . The total energy consumption is calculated assuming the lighting system runs for an average of 11 hours from evening to morning in a day. It is seen that most of the existing lamps are fluorescent tubes and flashlights having relatively higher electric consumption. The total daily energy consumption is calculated to be $61.78 \mathrm{kWh}$ per day which is substantial energy consumption. For maintaining similar illumination, two existing lamps can be replaced by two (light emitting diode) LED lamps having 20 watts each. As a result, total daily energy consumption from 126 pairs of LED lamps (126 electric poles) for same period of operation (11 hours) is calculated to be $55.44 \mathrm{kWh} /$ day which is lower than the existing system.

Table 1. Details of existing electric appliances at SUST.

\begin{tabular}{lccr}
\hline $\begin{array}{l}\text { Electric } \\
\text { appliances }\end{array}$ & Quantity & $\begin{array}{l}\text { Unit power } \\
\text { (in watts) }\end{array}$ & $\begin{array}{l}\text { Daily energy } \\
\text { consumption } \\
\text { (in kWh/day) }\end{array}$ \\
\hline $\begin{array}{l}\text { Energy savings } \\
\text { bulb }\end{array}$ & 32 & 23 & 8.10 \\
$\begin{array}{l}\text { Fluorescent tube } \\
\text { Flashlight bulb }\end{array}$ & 112 & 40 & 49.28 \\
& 8 & 50 & 4.40 \\
\hline \multicolumn{3}{c}{ Total }
\end{tabular}

\subsection{Design of the Solar PV System}

An off-grid system as a stand-alone PV system is considered in this research work. A simple schematic diagram for the solar PV street lighting system with its components is shown in the Figure 1. The has mainly five components, namely, a solar panel, charge regulator, battery and two LED lamps. In the present work, at first, a grid electricity based electric pole is designed as a solar PV based one and economic feasibility analysis is performed for the single electric pole. Finally, total financial analysis is carried out for the solar PV system for all 126 electric poles in the university campus. The total costings and benefits are simply the multiple of those associated with of a single electric pole.

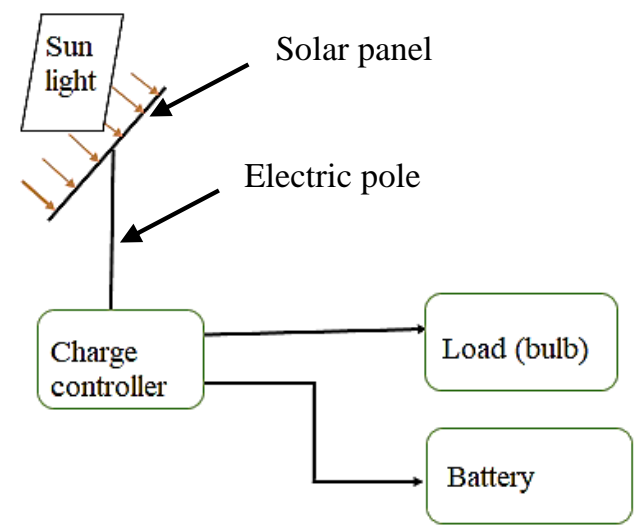


Figure 1. A simple schematic diagram for the solar PV street lighting system.

\section{Energy consumption and sizing of a PV panel}

The energy consumption of one electric poll for SUST solar street lighting project is shown in Table 2 .

Table 2. Daily energy consumption for an electric pole based on solar energy.

\begin{tabular}{ll}
\hline Particulars & Quantity \\
\hline LED bulb (load) & 2 \\
Unit power & 20 watts \\
Duration of running per day & 11 hours \\
Daily energy consumption & $0.44 \mathrm{kWh}$ \\
\hline
\end{tabular}

The required energy to supply from the solar system, $R_{e}$ is calculated from the ratio of the total energy consumption per day and the overall efficiency of different system components as below. In this work, the overall efficiency is considered $80 \%$.

$$
\begin{gathered}
R_{e}=\frac{\text { Daily energy consumption }}{\text { overall efficiency }} \\
R_{e}=\frac{R}{\eta_{\text {comp }}}=\frac{0.44 \mathrm{kWh}}{.8}=0.55 \mathrm{kWh}
\end{gathered}
$$

The peak power, $P_{e}$ can be determined by the ratio of $R_{e}$ and average sunshine hours in that location. The average sunshine hours in Sylhet region is reported to be about 6.6 hours/day[17].

$$
\begin{gathered}
P_{e}=\frac{R_{e}}{\text { average sunshine hours }} \\
P_{e}=\frac{0.55 \mathrm{kWh}}{6.6}=0.84 \mathrm{kWh}
\end{gathered}
$$

The total current for the solar PV system needed can be found by dividing the peak power with the system voltage as follows. For the low energy required, the system voltage is considered as $12 \mathrm{~V}$ for the present work.
As the solar PV system for street lighting is designed to work at night only, it is basically based on the storage battery. A cost-effective solar panel having a higher power (>>40 watts) and a short circuit current $(>7 \mathrm{~A})$ can be chosen. In this research, the solar panel was selected with Model Name: GOPV150Wp 156P 36 SERIES and the details are given in Table 3.

\section{Sizing of the DC battery and charge controller}

Total daily energy requirement for the street lighting is 550 Wh and two days are considered as the days of autonomy with one day without sun. Rough energy required is defined as the product of total energy and the days of autonomy, so it is $1100 \mathrm{Wh}$. For the safe storage of energy in battery, depth of discharge should be considered as $80 \%$. It means that 80 percent of the available energy will be delivered while 20 percent remains in reserve.

$$
\begin{gathered}
\text { Actual energy required }=\frac{\text { Rough energy required }}{\text { Depth of discharge }} \\
=\frac{1100}{0.8} \cong 1375 \mathrm{Wh}
\end{gathered}
$$

So, the capacity of the battery can be determined by the ratio of the actual energy required and the DC voltage of the battery. In this research work, a $12 \mathrm{~V}$ battery is considered complying with the system voltage adopted.

$$
\begin{gathered}
\text { Capacity of the battery }=\frac{\text { energy required }}{\text { battery voltage }}=\frac{1375}{12} \\
=115 \text { Ah }(\text { Ampere. } \text { hour })
\end{gathered}
$$

Therefore, a storage battery with good reliability and lifetime having higher capacity than $115 \mathrm{Ah}$. In this research, the model selected for storage battery having a capacity of $120 \mathrm{Ah}$ is also shown in Table 3. Depending on the system voltage and current, a charge controller is selected with a rated current and voltage of $10 \mathrm{~A}$ and $12 \mathrm{~V}$, respectively. The detail specifications of all components for the solar PV project for street lighting at SUST are given in the table and it also includes the approximate procurement costs for each components.

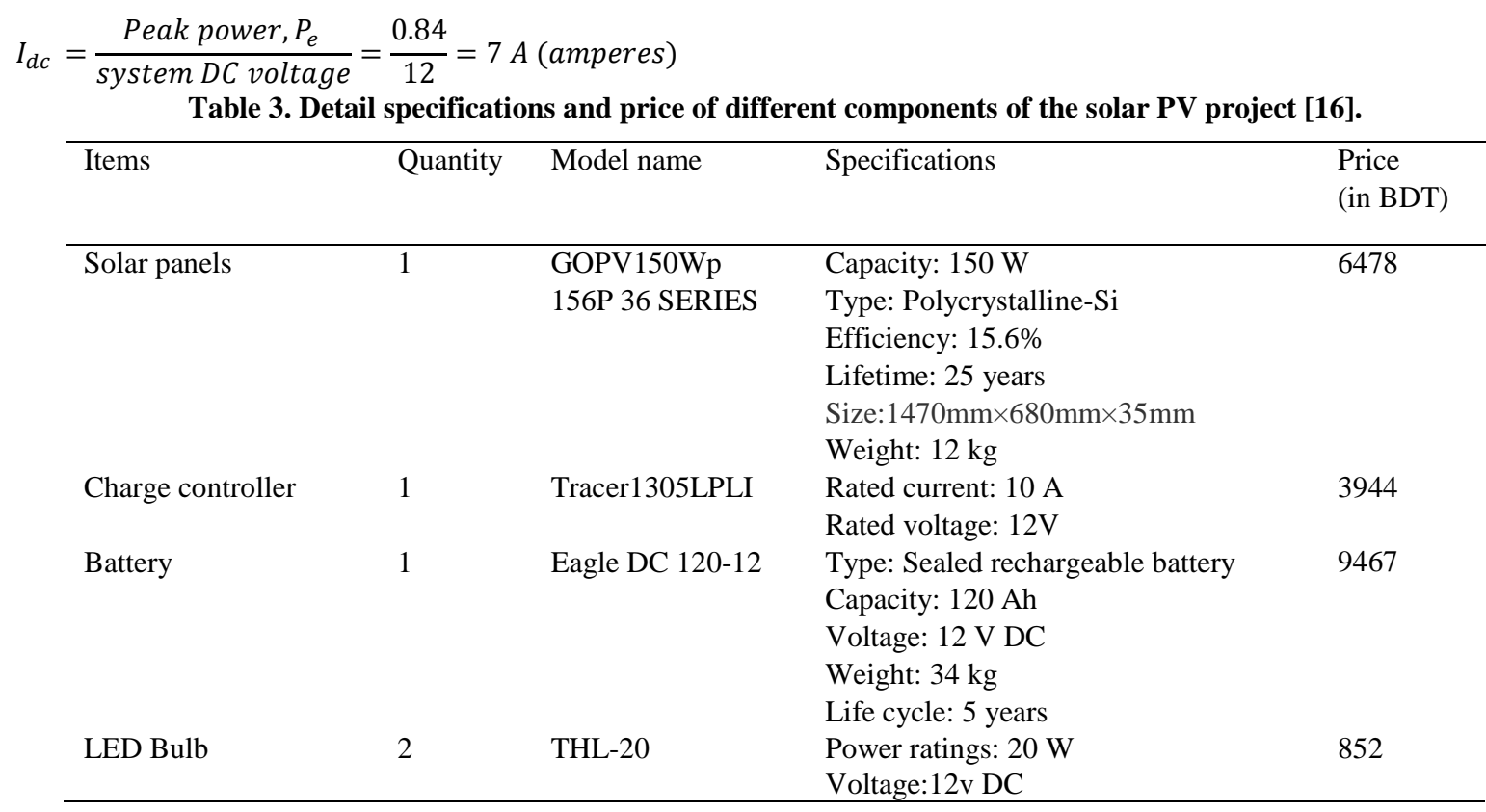


for this analysis. According to Bangladesh bank, the inflation rate and the discount rate or minimum interest rate in Bangladesh are found to be $5.5 \%$ and 5\%, respectively [18]. The fuel cost escalation rate is considered about $7 \%$. The electricity bill rate for the street lighting system for

\subsection{Cost Analysis}

The costs involved in the project lifetime include components' costs, operating and maintenance (O\&M) costs, installation costs and replacement costs. To find the replacement costs, it is necessary to find the lifetime of all components. As the selected LED bulbs have life hours about $50000 \mathrm{hrs}$. So, the light should be replaced after a certain period. Life time of LED bulb can be calculated assuming that it runs 11 hours per day and is given below:

$$
\begin{aligned}
& \text { Lifetime of an LED bulb }=\frac{\text { Working life time }}{\text { working hours per night }} \\
& =\frac{50000}{11} \text { hours }=\frac{4546}{365}=12.45 \text { years }
\end{aligned}
$$

So, every 12.5 years the LED lamps should be replaced and it is clearly observed that during the project life time of 25 years, they should be replaced once only. The installation cost is considered as $10 \%$ costs of solar panels. The operation and maintenance $(\mathrm{O} \& \mathrm{M})$ cost is assumed about $3 \%$ of $\mathrm{PV}$ cost. The costs for the solar PV street lighting project have been illustrated in Table 4.

The total development cost for the SUST street light system considers a single electric pole that is the sum of first four costs given in Table 4. And it is found to be BDT 22241. Battery warranty is one year, though its lifecycle is claimed as 5 years whereas the LED bulb has 12.5 years of working life time. The charge controller has warranty of three years and the solar panel has warranty of twenty-five years. Considering the warranty and their price, it is assumed that about $25 \%$ of the total cost of battery, panel and charge controller as replacement cost after each four years. So, the replacement cost is found to be about BDT 5000 after each four years.

Table 4. Costs for the SUST solar street lighting project consindering an electric pole.

\begin{tabular}{llrr}
\hline Items & Quantity & $\begin{array}{l}\text { Unit cost } \\
\text { (in BDT) }\end{array}$ & $\begin{array}{l}\text { Total cost } \\
\text { (in BDT) }\end{array}$ \\
\hline Solar panel & 1 & 6478 & 6478 \\
Battery & 1 & 9467 & 9467 \\
Charge controller & 1 & 3944 & 3944 \\
LED lamp & 2 & 852 & 1704 \\
Installation cost & 10\% of PV cost & 648 \\
Operation and & $3 \%$ of PV cost & 195 \\
maintenance cost & \multicolumn{3}{c}{} \\
per year & \multicolumn{3}{c}{ Total cost } \\
\hline
\end{tabular}

\subsection{Economic Analysis and Emission Impact}

Financial analysis is the process of determining the finance related activities for a certain project to check whether the project is producing substantial profit or not. It mainly deals with the income statement, balance sheet and the cash flow statement. RETscreen which is a renowned renewable energy technology software has been selected for the financial analysis. In this section financial analysis of the developed solar model has been analyzed. Several factors are considered
Bangladesh was considered as 7.17 BDT/kWh [19].

After considering all types of costs, required energy and present energy prices, the RETscreen software provided the project costs or saving income summary. On the basis of the fuel cost, the annual savings per year is about BDT 1430 . From the financial viability, the equity payback period (PBP) is found 13.6 years. The internal rate of return (IRR) is found to be $7 \%$ which is more than the discount rate $5 \%$ as considered. For verifying the results, the IRR and PBP values are also calculated using the Microsoft Excel and are found to be in a good agreement. The benefit cost ratio (BCR) is also found to be 2.6 which indicates the project as an economically viable one. The summary report of the financial viability using 'RETScreen' software is given in the Table 5.

Table 5. Financial viability of the solar PV project for street lighting.

\begin{tabular}{lll}
\hline Items & Unit & Rate/Amount \\
\hline Pre-tax IRR - equity & & $7 \%$ \\
Pre-tax IRR - assets & & $7 \%$ \\
After-tax IRR - equity & & $7 \%$ \\
After-tax IRR - assets & & $7 \%$ \\
Equity payback & Year & 13.6 \\
Annual life cycle savings & BDT/year & 1427 \\
Benefit-Cost (B-C) ratio & & 2.60 \\
Net present value & BDT & 35685 \\
\hline
\end{tabular}

The yearly cumulative cash flow using the RETscreen software is shown in Figure 2. When the income is higher than the expenses, the cash flow is positive. Again, when the income is lower than the expenses, the cash flow is found to be negative. In the break-even point, the total income equals to the total expenses is equal. The number of years required to reach break-even point is the payback period which is observed to be 13.6 years. As shown in the figure, the project investor is supposed to get profit after 13.6 years in a project life span of 25 years

Using the Microsoft Excel, the net present value of life cycle costing (LCC) is estimated to be about BDT 52850. The NPV for the proposed solar street lighting system is much more than zero. If the net present value(NPV) is greater than zero, it means that the project will add value to the farm or investor and create wealth for shareholders [14]. Therefore, it can be said that the solar PV project is going to create wealth for the shareholders. The above results in the present work is found to be in good agreement with the work by Sowe et al. [9]. In their work, they investigated on the economic viability of a cSi module based power plant and found that the IRR, PBP, BCR are 9\%, 8.35 years, 1.82 respectively. On the basis of the savings on electricity bills, the annual savings per year by implementing a solar system for an electric pole only is about BDT 1430 as mentioned earlier. A complete solar PV system for street lighting in SUST campus is expected to give a total annual savings of BDT 180,180.

The emission analysis is performed to determine annual reduction of $\mathrm{CO}_{2}$ gas emission by implementing the proposed PV system. In Bangladesh, grid electricity is produced from natural gas, petroleum, coals and hydroelectricity. Hossain et 
al. [20] reported in their thesis, an off-grid solar PV system is capable of reducing $506.3 \mathrm{~g}$ of $\mathrm{CO}_{2}$ by replacing $1 \mathrm{kWh}$ of grid electricity. From the data in Table 1, the total electricity consumption for all 126 electric poles in a day is estimated to be about $22550 \mathrm{kWh}$ annually. In this present work, replacing $22550 \mathrm{kWh}$ grid electricity by implementing the whole solar project is expected to reduce 11.42 tons of $\mathrm{CO}_{2}$ emission in a year. It is undoubtedly going to be a vital contribution to mitigate the global warming.

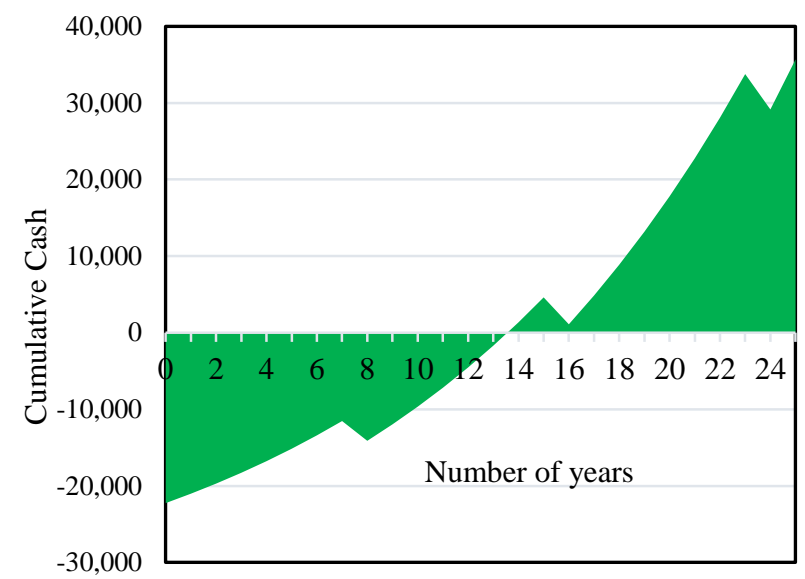

Figure 2. Cumulative cash flow graph for the solar PV project for the street lighting at SUST.

\section{CONCLUSIONS}

Increasing the share of renewable energy for the total energy consumption is a crying need for a developing country like Bangladesh. Financing a project based on renewable energy needs to be attractive and economically viable to prospective entrepreneurs. Solar irradiance in Bangladesh promises a better perspective of utilizing solar energy technologies. The present paper aims at investigating a current street lighting system for a university campus and designing a solar street lighting system to replace the existing system. It also evaluates financial and environmental benefits of the proposed solar street lighting system. A clean energy management software 'RETScreen' and Microsoft Excel were used for various analysis in the paper. With the project lifetime of 25 years, the equity payback period for the solar PV system is found to be 13.6 years. The net present value of life cycle costing (LCC) is estimated to be about BDT 52850 using the Microsoft Excel that is larger than that found using RETScreen (BDT 35690). The internal rate of return (IRR), and benefit cost ratio (BCR) are found to be $7 \%$ and 2.6, respectively. A complete solar PV system for street lighting in SUST campus is expected to give a total annual savings of BDT 180,180. As a result, it can be concluded that the implementation of the solar PV systems is economically viable. Moreover, a total reduction of 11.42 tons of $\mathrm{CO}_{2}$ emission per year is expected from replacing fossil fuel based generation which indicates a great environmental impact for the better world.

\section{ACKNOWLEDGMENTS}

The authors would like to thank the Department of Industrial and Production Engineering, Shahjalal University of Science and Technology (SUST), Sylhet, Bangladesh for the assistance to carry out this research work.

\section{REFERENCES}

[1] World Bank. 2019. Fossil fuel energy consumption (\% of total). Retrieved https://data.worldbank.org/indicator/ (Accessed on August 29, 2019).

[2] SREDA. 2019. Present status in Sustainable \& Renewable Energy Development Authority. Bangladesh, Retrieved from http://www.sreda.gov.bd/index.php/site/re_present status. (Accessed on August 29, 2019).

[3] Wadud, Z., Dey, H., Kabir, M.A. and Khan., S.I. 2011. Modeling and forecasting natural gas demand in Bangladesh. Energy Policy 39, 7372-7380.

[4] Lewis., N.S. 2007. Toward Cost-Effective Solar Energy Use. Science, 315(5813), 798-801.

[5] Baky, M.A.H., Rahman, M.M. and Islam., A.K.M.S 2017. Development of renewable energy sector in Bangladesh: Current status and future potentials. Renewable and Sustainable Energy Reviews 73, 11841197.

[6] Islam, M.R., Islam, M.Ra. and Beg., M.R. 2008 Renewable energy resources and technologies practice in Bangladesh. Renewable and Sustainable Energy Reviews 12(2), 299-343.

[7] Lewis, N.S. 2016. Research opportunities to advance solar energy utilization. Science 351(6271), aad1920-9.

[8] Kurniawan, A. 2016. A review of solar-powered boat development. The Journal for Technology and Science 27(1), 1-8.

[9] Sowe, S., Ketjoy, N., Thanarak, P. and Suriwong, T. 2014. Technical and Economic Viability Assessment of PV Power Plants for Rural Electrification in The Gambia. Energy Procedia 52, 389-398.

[10] Mondal, M.A.H. 2010. Economic viability of solar home systems, case study of Bangladesh. Renewable Energy 35(6), 1125-1129.

[11] Aung, N.S.M. and Myint, Z.H. 2014. Design of StandAlone Solar Street Lighting System with LED. International Journal of Scientific Engineering and Technology Research 3(17), 3518-3522.

[12] Omar, M.A. and Mahmoud, M.M. 2019. Design and Simulation of a PV System Operating in Grid-Connected and Stand-Alone Modes for Areas of Daily Grid Blackouts. International Journal of Photoenergy 2019, 5216583_1-9.

[13] Al-Shamani, A.N., Othman, M.Y.H., Mat, S., Ruslan, M.H., Abed, A.M. and Sopian., K. 2015. Design \& Sizing of Stand-alone Solar Power Systems A house Iraq. Proceedings of the 9th International Conference on Renewable Energy Sources, 23-25 April, 2015, Kuala Lumpur, Malaysia, 145-150 (ISBN: 978-1-61804-303-0).

[14] Magni, C. 2009. Investment decisions, net present value and bounded rationality. Quantitative Finance 9, 967-979.

[15] Hoekstra, R.L. 2017. Life Cycle Costing. Retrieved from http://c.ymcdn.com/sites/www.azace.org/resource/resmgr/ imported/Hoekstra_Life_cycle_training.pdf (Accessed on November 01, 2017).

[16] Alibaba. 2019. Solar battery, High efficiency solar panel and Solar Led light. Retrieved from https://www.alibaba.com/product-detail/ (Accessed on August 30, 2019). 
[17] Weather2visit. 2019. Sylhet monthly weather averages. Retrieved from https://www.weather2visit.com/asia/ bangladesh/ sylhet.htm (Accessed on September 01, 2019).

[18] Bangladesh Bank, 2017, Financial Stability Report, Retrieved from https://www.bb.org.bd/pub/annual/fsr/ final stability_report2017.pdf (Accessed on September 01, 2019).

[19] Bangladesh power development board. 2017. Commercial: Tariff-BPDB. Retrieved from http://www. bpdb.gov.bd/bpdb/index.php?option=com_content $\&$ view= article\&id=231\&Itemid=130, October 15, 2017.

[20]Hossain, M.A., Chowdhury, M.M.R. and Hossain, I. 2018. Design and feasibility study of a photovoltaic (PV) power generation system for a proposed academic building of SUST. Undergraduate thesis, Department of Industrial and Production Engineering, Shahjalal University of Science and Technology, Sylhet-3114, 